See discussions, stats, and author profiles for this publication at: https://www.researchgate.net/publication/327405433

\title{
Size, Density and Small Scale Elections: A Multi-Level Analysis of Voter Turnout in Sub-Municipal Governments.
}

Article in Electoral Studies · December 2018

DOI: 10.1016/j.electstud.2018.09.001

CITATIONS

9

2 authors:

António Tavares

University of Minho

69 PUBLICATIONS 1,029 CITATIONS

SEE PROFILE
READS

277

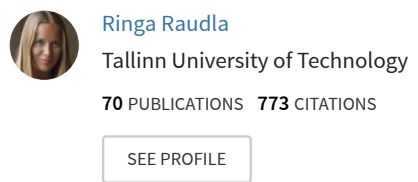

Some of the authors of this publication are also working on these related projects:

Experimental approaches and institutional innovations in the domains of fiscal and financial policy (PRG1125) View project

Institutions, local governance and land use changes - a comparative study of selected European countries View project 
Cite as:

Tavares, A., and Raudla, R. (2018). Size, Density and Small Scale Elections: A MultiLevel Analysis of Voter Turnout in Sub-Municipal Governments. Electoral Studies. Forthcoming.

\title{
Size, Density and Small Scale Elections:
}

\section{A Multi-Level Analysis of Voter Turnout in Sub-Municipal Governments}

\begin{abstract}
What are the consequences of fragmenting political and administrative authority within municipalities? Portugal provides an excellent setting to study the effects of sub-city institutional fragmentation because each of its 308 municipal governments is divided into sub-municipal governments (SMUs). The 4,259 SMUs deliver services to the residents and its executive leader serves on the city council. In this paper we investigate the determinants of voter turnout in these SMUs. We argue that the size and density of SMUs affects electoral participation, but this effect is mediated by the municipal context. High levels of population concentration and low levels of territorial fragmentation at the municipal level are expected to improve voter mobilization efforts and mitigate the negative effect of size and density on voter turnout. Hierarchical linear analysis of municipal and SMU data finds strong support for size and density effects and moderate support for multilevel relationships.
\end{abstract}

Keywords: voter turnout, electoral participation, sub-municipal governments, territorial fragmentation 


\section{Size, Density and Small Scale Elections:}

\section{A Multi-Level Analysis of Voter Turnout in Sub-Municipal Governments}

\section{Introduction}

Recent studies suggest that local political participation is a function of the size and concentration of a jurisdiction's population. Most of this research focuses on the idea that there is an "optimal" size and concentration of population that favours active political participation in terms of higher propensity to vote in local elections, contact local officials and attend community meetings (Oliver 2001). The conventional argument suggests a negative relationship between jurisdiction size and political participation (Oliver 2001), mitigated to some extent by the deeper social interactions generated by higher population density (Tavares and Carr 2013, 2014).

These studies have been conducted at the municipal level, often ignoring the fact that, in many countries, municipalities are themselves divided into sub-municipal governments that are elected. Recent contributions attempt to mitigate the paucity of research on sub-municipal governments (Swianiewicz, 2014; Tavares and Rodrigues 2015; Hlepas et al. 2018) but fail to explain how these systems might affect political participation in general and voter turnout at the sub-municipal unit (SMU) level in particular.

Our paper addresses this gap in the existing literature and investigates - both theoretically and empirically - the determinants of electoral participation in SMUs. Drawing on existing research, we develop a set of hypotheses. We argue that population 
size and density of SMUs negatively affect the propensity to vote, but this effect is mediated by the municipal context where these SMUs operate. First, the level of population concentration ${ }^{1}$ in a single or few SMUs mitigates the negative effects of both size and density on voter turnout, because these SMUs will have the institutional capacity to address larger policy questions, much in the same way a municipality would. In addition, population concentration reduces the spatial mismatch between problems and venues with the authority and resources to develop and implement solutions (Kelleher and Lowery 2004). In turn, excessive territorial fragmentation of a municipality into SMUs is expected to have a negative effect on electoral participation, since it increases the likelihood that dissatisfied citizens will find an alternative SMU that better matches their preferences. This reduces the investment benefit from voting, given that the existence of a wider range of location options makes the 'exit' option more credible and diminishes the relevance of 'voice' as an alternative form of participation in local politics, as suggested in the voice-substitution hypothesis proposed by Kelleher and Lowery (2004).

We test the hypotheses using the case of Portugal. The Portuguese case constitutes an excellent opportunity to study the effects of municipal and sub-municipal factors on voter turnout in SMUs. First, in terms of the existence of SMUs, Portugal stands out as the extreme case: all its municipalities have SMUs. At the other extreme there are some countries (e.g. Belgium and Norway) where only one city has a sub-municipal level,

\footnotetext{
${ }^{1}$ Kelleher and Lowery (2004: 730) define the level of population concentration as "how dispersed the population of the metropolitan area is across the local governments within it", Here, we adapt this definition to mean how dispersed the population of the municipality is across the sub-municipal governments within it.
} 
whereas many countries fall in between (e.g. Spain, Greece, the Czech Republic, England, Germany, Poland) (Hlepas et al. 2018). Second, although in most countries in Europe that have SMUs, there are district elections at the SMU level (except urban SMUs in Spain and varying practices between SMUs in Slovenia and England) (Hlepas et al. 2018), the legislative framework gives the municipal level considerable freedom in defining these electoral rules, whereas in Portugal, SMUs are subjected to similar electoral rules. Finally, in many countries, there is an enormous range of sub-municipal structures used to deliver local services, whereas the homogeneity of sub-municipal institutions in Portugal provides a unique opportunity for comparative analysis. Portugal's 308 local governments are subdivided into 4,259 civil parishes (freguesias). These sub-municipal governments are autonomous democratic institutions that have elected councils and chief executives. They receive funding from the national government and the municipal governments but also raise a portion of their budgets from own-source revenues. They have the authority to determine the levels of selected services for the residents living within the SMU.

The empirical analysis employs a multilevel model to test the hypotheses developed in the theoretical discussion, taking as the unit of analysis the 4,259 SMUs (level 1 units) distributed over 308 municipalities (level 2 units). Hierarchical linear analysis of data for municipal and sub-municipal governments finds strong support for size and density effects and moderate support for multilevel relationships.

The paper proceeds as follows. The second section presents the theoretical discussion and develops the hypotheses. The third section describes the context of our 
study. Data and methods are presented in section four and the findings reported in section five. The final section outlines our conclusions and discusses implications for future research.

\section{Analytical Framework}

The political science literature recognizes the complex relationship between jurisdiction size, population concentration, and political participation. This section draws on general theoretical arguments and prior empirical findings to develop hypotheses about electoral participation in SMUs as the first step and then discusses the influence of the municipal setting on SMU voter turnout as the second step.

\subsection{Size, Density, and Electoral Participation}

From the perspective of an individual, the decision to vote is influenced by expected benefits and costs (e.g. Downs 1957; Brennan and Lomasky 1997; Fiorina 1976; Matsusaka 1995; Riker and Ordeshook 1068; Struthers and Young 1989). One of the most often-used equations employed for characterizing that decision is:

$$
\mathrm{R}=\mathrm{PB}+\mathrm{D}-\mathrm{C}
$$

Where: $\mathrm{R}=$ the reward for voting $\mathrm{B}=$ investment benefits, $\mathrm{D}=$ consumption benefits, and $\mathrm{C}=$ costs.

The investment (also called instrumental) benefit of voting (B) entails the benefit the voter gains from having their preferred candidate or party win (Kaniovski and 
Mueller 2006). The consumption benefits (also called 'expressive' benefits by Fiorina (1976)) refer to the gratification gained from the act of voting itself: experiencing the entertainment value of the occasion, the desire to express their preferences, the affirmation of group solidarity, the feeling of fulfilling a civic duty, or the influence of peer pressure (e.g. Brennan and Lomasky 1997; Kaniovski and Mueller 2006; Riker and Ordeshook 1968; Schuessler 2000; Struthers and Young 1989).

The size of the jurisdiction is likely to influence both the instrumental and consumption benefits of voting. According to the 'rational voter' model (Downs 1957), the expected investment benefit of voting increases with the probability of affecting the election result, which, in turn, is influenced by the size of the population: the smaller the population, the higher the probability of casting the decisive vote (Geys 2006; Riker and Ordeshook 1968). Thus, the smaller the population of the jurisdiction, the higher the voter turnout is likely to be since few votes can make a difference and voters feel they can influence the outcome of the election (Wood 2002). Municipal size is also likely to affect the consumption benefits associated with voting, although here the effect could go both ways. On the one hand, smaller size could lead to higher turnout. A smaller polity may offer citizens a greater sense of solidarity and sense of belonging (Dahl and Tufte 1973). In smaller communities, elected representatives are seen as friends and neighbours, who reflect community values and respond to the needs of the residents (Ross and Levine 2001). All of these increase the social pressure and perceived duty to vote (Ladner 2002) and lead to a loss of social prestige or reputation for individuals who do not participate in elections (Riker and Ordeshook 1968; Oberbye 1995). In contrast, in larger communities, political life tends to be more impersonal and distant (Verba and Nie 
1972) and the elected officials become viewed as detached and unresponsive officials (Ross and Levine 2001), leading to lower voter turnout. In smaller jurisdictions, residents are more animated by local issues and can be more easily mobilized to vote (Oliver and Ha 2007; Oliver 2012). It has also been argued that voters feel 'less qualified' to participate in elections if the district size increases (Lassen and Serritzlew 2011; Oliver 2001). The larger the jurisdiction, the more complex the government, and hence the more important the individual skills and resources necessary for civic participation, including voting (Oliver 2001). On the other hand, elections in a larger jurisdiction are likely to provide voters with a larger choice set of candidates, making it more likely that they find a candidate who fits their preferences (Dahl and Tufte 1973), which is likely to increase turnout.

The existing empirical evidence provides extensive support for the negative effect of population size on voter turnout, especially at the subnational level (Cancela and Geys 2016; Carr and Tavares 2014; Geys 2006; Sellers et al. 2013), although there are also some studies that fail to substantiate that claim (e.g. for overviews, see Cancela and Geys 2016 and Geys 2006). In the Portuguese context, Tavares and Carr (2013) analyze civic participation activities in the 278 municipalities of continental Portugal and find that population size is negatively correlated with voter turnout. They conclude that the effect of population size on electoral participation can be summarized in the general principle that residents in larger cities are less socially connected with their neighbors, less interested in local politics and less active in local civic affairs. 
In addition to the sheer size of the jurisdiction, the individual's choice to participate in the election can also be influenced by the population density, referring to population per square kilometer. Population density is likely to influence the expressive (or consumption) benefits and also costs related to voting. On the one hand, it can be argued that the lower the population density, the higher the turnout rate. First, in low-density areas, elections are likely to be more 'personal' (which reduces the information costs involved in deciding between the candidates) (Blank 1974; Geys 2006; Oliver 2012). Second, in low-density areas there is more likely to be 'social pressure' (i.e. higher expressive benefits) to vote than in more anonymous high density areas, where there are weaker social bonds (e.g., Hoffman-Martinot 1994; Oliver 2012; Overbye 1995). On the other hand, in high density areas (which are usually urban), there are more opportunities for interaction, civic engagement, mobilization, and hence also more group pressure to vote, which may have a positive effect on turnout (Blais and Dobrzynska 1998; Kelleher and Lowery 2004; Tavares and Carr 2013). In line with the diverging theoretical predictions, the existing empirical evidence for the effect of population density is mixed (for overviews, see Geys 2006; Cancela and Geys 2016).

Tavares and Carr (2013) argue that the lack of empirical support for the density hypothesis is due to the failure of prior studies to properly examine the mediation effects of density on the relationship between population size and voter turnout. They argue that higher population density can mitigate the negative effect of scale in larger jurisdictions through group mobilization and thus increase the likelihood of participation (Tavares and Carr 2013). Population density can facilitate the creation of dense social networks that encourage participation, including voting. Neighbors in close proximity are more likely 
to come into contact, to share concerns about common problems, and to get organized for civic action (Stein and Dillingham 2004). In addition, proximity facilitates mobilization by allowing significant cost savings in communication and information dissemination. This argument is supported by their study of Michigan cities, where Carr and Tavares (2014) find that population density can mitigate the negative effect of population size and increase the likelihood of voting.

Given the ambivalent theoretical predictions and mixed set of findings concerning the effects of size and density on electoral participation, the hypotheses about the effects on voter turnout at sub-municipal elections are not expressed in terms of a positive or negative expectation:

$\mathbf{H}_{1}$ : Population size of SMUs affects voter turnout rates.

$\mathbf{H}_{2}$ : Population density of SMUs affects voter turnout rates.

$\mathbf{H}_{3}$ : Population density has a contingent effect on the relationship between SMU size and voter turnout rates.

\subsection{Territorial Fragmentation, Population Concentration, and Electoral Participation}

When examining voter turnout at the sub-municipal elections, it would also be relevant to explore the effects of the territorial fragmentation of the municipality (i.e. the number of sub-municipal units in it) and the concentration of population (i.e., how 
dispersed the population of the municipality is between the sub-municipal units) since these aspects are likely to influence the benefits of voting.

According to the argument derived from public choice theory, it is not the size or other features of the jurisdiction itself that matters but the configuration of the local political economy (Oakerson 1999; Oakerson and Parks 2011). The presence of a large number of SMUs increases the likelihood of dissatisfied citizens finding an alternative that better matches their preferences, which reduces the investment benefit from voting. The existence of a wider range of location options makes the 'exit' option more credible, diminishing the relevance of 'voice' as an alternative form of participation in local politics. This is the voice substitution hypothesis suggested by Kelleher and Lowery (2004; 2008). The credibility of the 'exit option' does not require that a large number of citizens routinely 'vote with their feet'. Rather, it is the threat of the 'exit option' that matters politically (Schneider 1989) and this increases as the number of jurisdictions also increases.

Although the level of territorial fragmentation has been the subject of interest in the literature of political participation in the U.S. context (Kelleher and Lowery 2004) ${ }^{2}$ to date, no empirical work has focused on how the level of sub-municipal fragmentation affects voter turnout in these smaller jurisdictions. In this particular instance, Portugal provides quite a contrasting case to the U.S., for at least two reasons ${ }^{3}$. First, Portugal is

\footnotetext{
${ }^{2}$ Kelleher and Lowery $(2004,2008)$ explore how municipal fragmentation influences voter turnout at the municipal level, whereas our focus is the turnout at the SMU level.

${ }^{3}$ We are grateful to a reviewer for pointing these out to us.
} 
characterized by a relatively high rate of home ownership, but the residential mobility rate is one of the lowest in Europe according to Eurostat ${ }^{4}$. This combination of features suggests that, unlike their U.S. counterparts, Portuguese citizens are much less likely to 'vote with their feet'. Second, the main (and the majority) of local government attributions are located at the municipal level of government, not the SMU level, thus creating less pressure for citizens to move inside their municipality. Nevertheless, the dual local government system allows us to test these possibilities regarding exit versus voice options in a novel context. We will test this hypothesis in the Portuguese context with this caveat in mind.

According to the voice substitution hypothesis, we can expect that:

$\mathbf{H}_{4}$ : SMUs in more fragmented municipalities are likely to display lower turnout rates.

Besides territorial fragmentation, the level of population concentration in a municipality is also likely to affect electoral participation in their SMUs (Kelleher and Lowery 2008). Population can be highly concentrated in a large city center, with relatively small suburbs, or evenly distributed across a number of SMUs of similar size. If the population is evenly distributed across the SMUs that compose the municipality, we can expect very different outcomes from a situation where the population is concentrated in only one or few SMUs. Drawing on the argument from the new regionalists, Kelleher and Lowery (2004) argue that it is not the population within a jurisdiction that determines the levels of

\footnotetext{
${ }^{4}$ http://ec.europa.eu/eurostat/statisticsexplained/images/7/79/Population_having_moved_within_the last_fiveyear_period $\% 2 \mathrm{C}$ by tenure_status $\% 2 \mathrm{C} \_2012$ _28\%25_share\%29_PITEU17.png
} 
participation, but how effective is the scope of local government in dealing with the problems faced by the community in this area. Thus, participation will increase in heavily concentrated municipalities, since at least one jurisdiction will have the scale of political competence that better matches the scale of the problems to be addressed (Kelleher and Lowery 2004: 730), thus potentially increasing the investment benefits of voting. ${ }^{5}$ In addition, population concentration in one SMU is also likely to lead to positive spillovers across other SMUs inside the same municipality, leading to increased participation. According to this argument, the hypothesis predicts that:

H5: SMUs in more concentrated cities are likely to display higher voter turnout rates.

\subsection{Cross-Level Interaction Hypotheses}

In the previous subsections, we defined the hypotheses concerning the direct causal relationships between our explanatory variables and electoral participation. This section derives two hypotheses resulting from the interaction between variables at both levels of analysis. The first hypothesis suggests that sub-municipal fragmentation has an impact on the negative relationship between parish size and electoral participation. The direction of this effect is directly derived from $\mathrm{H}_{4}$. If we believe that the availability of a large number of location options makes the 'exit' option more credible and reduces the relevance of 'voice' (voting) as an alternative form of participation in local politics, then submunicipal fragmentation will have a negative effect on the relationship between SMU

\footnotetext{
${ }^{5}$ Kelleher and Lowery's empirical findings suggest that "although not [statistically] significant, the estimate for this interaction is negative, indicating that it is the turnout in smaller cities that increases the most as concentration levels rise." (2004: 748).
} 
size and electoral participation. In other words, large SMUs in highly fragmented municipalities will display lower turnout rates.

$\mathbf{H}_{6}$ : Territorial fragmentation at the municipal level deepens the negative effect of population size on voter turnout rates at the SMU level.

Our final hypothesis argues that population concentration has the potential to mitigate the negative effect of size on SMU electoral participation. The reason is that the concentration of population in a single or a few SMUs is likely to produce one or more

jurisdictions that are better able to address larger scale policy issues (Kelleher and Lowery 2004; 2008). Taking this argument to the limit, SMU-municipal government 'consolidation' provides the best setting to mitigate the negative effects of size. In fact, this is also compatible with $\mathrm{H}_{6}$, since the positive effect of this type of consolidation is consistent with a mitigating effect of low levels of fragmentation $\left(\mathrm{H}_{6}\right)$.

$\mathbf{H}_{7}$ : Population concentration at the municipal level mitigates the negative effect of population size on voter turnout rates at the SMU level.

\section{Research Context: The Portuguese Local Government System}

The unique nature of the Portuguese local government system and the analysis of cross-level interaction effects on SMUs electoral participation require a brief account of SMUs and municipal governments and their role in the Portuguese local government system.

\subsection{Sub-Municipal Governments (Freguesias)}


The freguesias are the smallest unit of local self-government in Portugal and their boundaries are completely contained within a single municipality. The number of SMUs per municipality varies significantly, ranging from one (in five municipalities ${ }^{6}$ ), where the boundary of the freguesia coincides with the boundary of the municipality, up to 89 (Barcelos), where each SMU is essentially equivalent to a neighborhood government. Tables 1 and 2 illustrate the extent of this sub-municipal polycentricity in Portuguese municipalities. Table 1 shows that some SMUs are extremely small: 177 (4.16\%) have less than 150 registered voters and 1,989 (46.79\%) have between 150 and 1,000 registered voters. Table 2 demonstrates that the variation in SMU size is also territorial: almost half of the freguesias have less than 10 square kilometers and only a couple of hundred are larger than 50 square kilometers.

[Insert Tables 1 and 2 here]

SMUs have democratically elected leaders, including both an executive and a legislative body. The SMU council (Assembleia de Freguesia) is a deliberative body elected by the municipality's registered voters residing in the territory of the freguesia. SMU council size is determined according to the rules in Table 3. The SMU executive (Junta de Freguesia) is composed of the president and a variable number of cabinet members, two of which will serve as secretary and treasurer. The SMU president is the first candidate on the list receiving most votes to the SMU council. The size of each SMU executive also varies according to the number of registered voters. The rules are also presented in Table 3.

${ }^{6}$ Alpiarça, Barrancos, Porto Santo, São Brás de Alportel e São João da Madeira. 
[Insert Table 3 here]

The responsibilities of SMUs are assigned by law and include the management of rural and urban infrastructure, preschool and elementary school buildings, cemeteries, public kennels, and vacant lands. SMUs also have powers assigned by national legislation to engage in emergency management, planning, and community development. In some cases, municipal governments delegate tasks to SMUs, including funding and managing physical infrastructure.

\subsection{Municipalities}

Mayors in Portugal are elected as the head of their party's lists. Local elections are mostly partisan although citizen organizations can present lists. One of the unique traits of the executive branch of local government is the formation of minority executives, a product of multiparty elections and proportional representation. On rare occasions, the winning party (and the mayor in office) may not have the majority of members in the cabinet executive. Municipal councils are responsible for budget approval, set up land use plans, sell municipal bonds, set municipal tax rates, and approve local ordinances and regulations. National legislation imposes a mixed composition of the municipal council combining SMU presidents and at-large elected members. SMU presidents can never outnumber council members elected at-large. As a general rule, the number of members elected at-large exceeds in one the number of SMU representatives. Consequently, municipal council size varies with the level of fragmentation of the municipality in SMUs. In municipalities with only a few SMUs, the minimum number of council members elected is 15 , corresponding to three times the number of members of the 
municipal executive. Table 4 displays the number of SMUs per municipality in Portugal (including the Azores and Madeira islands).

[Insert Table 4 here]

The Portuguese context provides an excellent opportunity to measure the effects of submunicipal fragmentation because the city council structure based on the number of SMUs was established by national legislation in 1976 and has remained unchanged for the past 38 years. In this context, sub-municipal fragmentation can be treated as exogenous by empirical models, since the factors accounting for the choice of government structures are uncorrelated with civic and political participation levels.

\section{Data and Methods}

This research follows a non-experimental design with cross-sectional data. The unit of analysis is the population of Portuguese SMUs (4,259 in total). We seek to identify and test the determinants of electoral participation at the sub-municipal level. The central argument is that the level of electoral participation is not only determined by a set of explanatory variables at the SMU level (level 1) but also by factors present at the municipal level (level 2). It is expected that SMUs belonging to the same municipality will exhibit similar levels of participation, so that contextual variables at the municipal level provide an additional explanation for the variation across SMUs. Furthermore, we also expect cross-level interactions between variables at both levels. 
The terminology of hierarchical linear models (HLM) is adequate to describe the structure of the Portuguese local government system. The 308 municipalities (level 2 units) are subdivided into 4,259 SMUs (level 1 units). The widespread use of a single level of analysis to test hypotheses in an intergovernmental context such as this is largely explained by the absence of sufficient data to allow the construction of multilevel explanations. Models using a single level of analysis to study hierarchical data are inadequate because they fail to provide an accurate theoretical account of reality and because they involve serious statistical problems leading to biased results (Lee and Bryk 1989; Raudenbush and Bryk 1986, 2002). As stated by Cho et al. (2006: 159), "the main difficulty with the traditional linear model for (this type of) data is that it rests on a basic assumption of independence", even though our SMU observations are grouped in municipalities. Zhu (1997) argues that for hierarchical data structures such as those studied here, the unit of analysis should be extended to include more than one level. In other words, in multilevel analysis, the variation in the dependent variable measured at the lowest level of analysis includes information on more than one level of analysis (Steenbergen and Jones 2002).

Three reasons justify the use of HLMs to analyze intergovernmental relations at the local level. First, HLM accounts for the factors that determine turnout in Portuguese SMUs embedded in their municipalities, allowing the inclusion of explanatory variables at different levels in a single comprehensive model (Steenbergen and Jones 2002). In the intergovernmental context, this means that the electoral participation in SMUs varies both within and between municipalities. Failure to account for the variables at the municipal level would result in the underestimation of standard errors and type I errors 
(Raudenbush and Bryk 2002). The second theoretical reason relates to how the explanatory factors at the municipal level can interact with those at the SMU level to shape electoral participation. This problem is known in the political science literature as causal heterogeneity (Western 1998), describing the possibility of cross-level interactions, and in this case, the variation of coefficients of SMU-level predictors as a function of municipal-level characteristics. Finally, the use of a single level of analysis in presence of hierarchical data often leads to aggregation bias as a result of the combination of data at a higher level of analysis, ignoring that a variable can have different meanings and effects at different levels. HLMs take into account the separate effects of similar variables by including the observed relationships between variables into separate level-1 and level-2 components (Raudenbush and Bryk 2002).

We analyze electoral participation in the 2009 SMU council elections in the 4,259 SMUs in the 308 Portuguese municipalities using the HLM following the standard form:

$$
Y_{\mathrm{ij}}=\beta_{0 \mathrm{j}}+\beta_{1 \mathrm{j}} X_{1 \mathrm{ij}}+\varepsilon_{\mathrm{ij}}
$$

Where $Y_{\mathrm{ij}}$ is the dependent variable of SMU i $\left(=1, \ldots, \mathrm{N}_{\mathrm{j}}\right)$ nested in municipality $\mathrm{j}(=1$, .., J). The term $X_{1 \mathrm{ij}}$ is an independent variable observed at the SMU level and $\varepsilon_{\mathrm{ij}}$ is the residual at the SMU level. In practice, the model is identical in all respects to the single level regression model, except for the fact that it allows for variation in the parameters across the second-level units, as indicated by the indexes $\mathrm{j}$ and parameters $\beta_{0 \mathrm{j}}$ and $\beta_{1 \mathrm{j}}$. At level 2, the individual regression parameters are modeled as functions of the explanatory factors at the municipal level. Here we derive, 


$$
\beta_{0 j}=\gamma_{0 o}+\gamma_{01} Z_{1 j}+\delta_{0 j}
$$

And

$$
\beta_{1 j}=\gamma_{1 \mathrm{o}}+\gamma_{11} Z_{\mathrm{j}}+\delta_{1 \mathrm{j}}
$$

The equations above represent the second level, where the parameter $Z_{l j}$ in equation (2) affects $Y_{\mathrm{ij}}$ and varies only across and not within municipalities with some error $\delta_{0 \mathrm{j}}$. Equation (3) represents the interaction between $X_{\mathrm{ij}}$ and $Z_{1 j}$ to determine the outcome, $Y_{\mathrm{ij}}$. The complete model is obtained by substituting the expressions in equation (1). Thus:

$$
\begin{gathered}
Y_{\mathrm{ij}}=\gamma_{0 \mathrm{o}}+\gamma_{01} \mathrm{Z}_{\mathrm{j}}+\delta_{0 \mathrm{j}}+\left(\gamma_{1 \mathrm{o}}+\gamma_{11} \mathrm{Z}_{\mathrm{j}}+\delta_{1 \mathrm{j}}\right) X_{\mathrm{ij}}+\varepsilon_{\mathrm{ij}} \\
=\gamma_{0 \mathrm{o}}+\gamma_{01} Z_{\mathrm{j}}+\gamma_{1 \mathrm{o}} X_{\mathrm{ij}}+\gamma_{11} \mathrm{Z}_{\mathrm{j}} X_{\mathrm{ij}}+\delta_{0 \mathrm{j}}+\delta_{1 \mathrm{j}} X_{\mathrm{ij}}+\varepsilon_{\mathrm{ij}}
\end{gathered}
$$

Where $\gamma_{0 \mathrm{o}}$ is the constant, $\gamma_{01}$ denotes the effect of the independent variable at level 2 (municipality), $\gamma_{10}$ is the effect of the independent variable at the SMU level, $\gamma_{11}$ is the interaction effect between levels 1 and 2, i.e., the interaction between the factors at the SMU and municipal levels with the residual terms represented by $\delta_{0 \mathrm{j}}, \delta_{1 \mathrm{j}}$ and $\varepsilon_{\mathrm{ij}}$.

\section{Dependent Variable}

The dependent variable is the voter turnout for each SMU council in the 2009 local elections $\left(Y_{\mathrm{ij}}\right)$ measured as the number of voters over the total registered voters in each SMU unit. Only 4,117 elections were held for the SMU councils. The remaining 142 SMUs operate as town meetings due to their extremely small size (less than 150 voters).

\section{Theoretical Variables}


In order to analyze the effects of jurisdiction size and population density in electoral participation we include population $\left(X_{1 \mathrm{j}}\right)$ and population density $\left(X_{2 \mathrm{j}}\right)$ as level 1 variables. The first variable is measured by the natural log of sub-municipal population in order to meet the assumption of normality. Density is measured as the sub-municipal population per square kilometer, also in natural log form. The effect of density on the relationship between population size and electoral participation is also tested, following suggestions by Stein and Dillingham (2004) and Tavares and Carr (2013).

Territorial fragmentation is measured by the natural log of the number of SMUs per municipality $\left(X_{\mathrm{i} 3}\right)$. The unlogged values indicate that the mean fragmentation level is 13.4 parishes per municipality ranging from a minimum of 1 in two municipalities and a maximum of 89 . Population concentration is measured by a Herfindahl index. The mean concentration level is .14 , the standard deviation is .11 and the index ranges from a minimum of .02 to a maximum of 1 . Concentration levels are generally low, with the obvious exception of municipalities with only one SMU. The simple correlations between our theoretical variables are negligible. SMU size and municipal fragmentation (.014), SMU size and concentration (.05), and fragmentation and concentration (-.035) are all barely correlated. As expected, the only exception to these values is the strong correlation between SMU size and density (.76).

\section{Control Variables}

The analysis includes two sets of control variables. The first group includes several socioeconomic characteristics of the SMUs and municipalities: age, education, income, 
and religion. Age $\left(X_{3 \mathrm{j}}\right)$ is measured by the proportion of population over 65 years-old in each SMU unit. The models also include Age as a level 2 predictor $\left(X_{\mathrm{i} 5}\right)$ measured as the municipal population over 65 years-old. A negative coefficient is expected, assuming that the propensity to vote decreases in the last stage of the life-cycle (Blais et al. 2004). Education $\left(X_{4 \mathrm{j}}\right)$ is the proportion of SMU population with high school education ${ }^{7}$. A positive coefficient is expected (Squire et al. 1987; Verba et al. 1995; Blais and Dobrzynska 1998). Income $\left(X_{\mathrm{i} 7}\right)$ and Religiousness $\left(X_{\mathrm{i} 10}\right)$ are measured by proxies at the municipal level: the average monthly earnings and the proportion of Catholic weddings, respectively. The use of data at the municipal level for the religiousness variable is also due to the unavailability of information at the SMU level. This variable should present a positive relationship with electoral participation because it can also be regarded as a direct empirical measure of the construct of social connectedness (Blais et al. 2004; Freire and Magalhães 2002; Magalhães 2001; Tavares and Carr 2013; Timpone 1998). We also include municipal population size $\left(X_{\mathrm{il}}\right)$ and density $\left(X_{\mathrm{i} 2}\right)$ as level 2 controls to provide context for electoral participation at the SMU level. A dummy variable $\left(X_{8_{\mathrm{j}}}\right)$ is included indicating all SMUs located in the Azores and Madeira Islands. A negative coefficient is expected due to the presence of an intermediate (regional) level of government, which may diminish the relevance of local elections in these archipelagos ${ }^{8}$.

\footnotetext{
${ }^{7}$ Education is not included at the municipal level due to missing data in a few municipalities resulting in the loss of 112 observations. We included this variable in specification A (see Appendix A). The sign of the variable is positive and consistent with the prediction included in Table 5 and the findings for the same variable at the municipal level.

${ }^{8} \mathrm{We}$ are grateful to an anonymous reviewer for pointing out this possibility to us. Another reviewer also stresses the divide between coastal and inland municipalities in Portugal. In our opinion, the Interiority variable suggested by this reviewer cannot fully capture the argument of remoteness and lack of prosperity of inland Portugal. Instead, we included the variable 'Urban Land Use', which is better able to grasp this
} 
The second set of controls refers to political variables. Interparty competition is measured by the difference in percentage points between the winner and the runner-up in each SMU election, i.e., the margin of victory $\left(X_{5 \mathrm{j}}\right)$. A negative coefficient is expected as more competitive elections should stimulate voter turnout (Franklin 2003; Wood 2002). The HLM also includes the margin of victory in mayoral elections (Xi9) and electoral participation in mayoral elections $\left(\mathrm{X}_{\mathrm{i} 11}\right)^{9}$ as level 2 political controls. Political fragmentation $\left(X_{6 \mathrm{j}}\right)$ is measured as the number of candidates in each parish election and a negative coefficient is expected. The argument is that an increase in the number of candidates decreases the investment benefits of voters due to the potential formation of post-election coalitions and party alliances (Blais and Dobrzynska 1998; Jackman 1987; Jackman and Miller 1995; Kostadinova 2003). Furthermore, it increases the complexity of the political system (Blais and Dobrzynska 1998), implying higher decision-making costs for the voters. The number of candidates without a national party affiliation $\left(X_{7_{\mathrm{j}}}\right)$ is also included and a positive coefficient is expected, given that independent lists might be able to mobilize otherwise apolitical voters (Aars and Ringkjob 2005; Freire et al. 2012). Finally, we included a variable to account for media competition in the municipality $\left(X_{\mathrm{i} 8}\right)$. The rationale for this is that increased competition reduces information asymmetry between candidates and voters and improves participation (Downs 1957; Filla and Johnson 2010; Squire and Smith 1988). The variable is measured as the sum of local newspapers and radio stations and is expected to have a positive coefficient, assuming

idea. Specification B in Appendix A reports the results for this variable, showing that, all else equal, urban areas are more likely to display higher turnout rates at the SMU level.

${ }^{9}$ Given that the elections for the municipal assembly (deliberative body), municipal executive and SMU assembly take place simultaneously, it is important to control for voter turnout at the municipal level. 
that greater disclosure and dissemination of information contributes to increased participation in local elections. All variables, indicators, sources and expected signs are included in Table 5.

[Insert table 5 here]

\section{Empirical Findings}

Table 6 presents the descriptive statistics for our level-1 and level-2 variables. The average of the dependent variable - electoral participation in sub-municipal elections - is $65.54 \%$, ranging between a minimum of $31.36 \%$ and a maximum of $92.11 \%$ with a standard deviation of 9.5, suggesting a normal distribution for this variable. ${ }^{10}$

[Insert Table 6 here]

The inferential analysis conducted in this section takes an incremental approach. It begins with a simple model without any predictor variables (the reference model) and builds increasingly complex estimations. The "optimal model" is given by the likelihood ratio test, which compares the goodness of fit of a more complex model with the quality of the adjustment of a simpler model, nested in the first. In other words, the objective is to maximize the likelihood function, which is the probability of observing the values of the dependent variable based on the validity of the assumptions of the model. There are two functions used in HLMs: classical maximum likelihood (ML) and restricted

\footnotetext{
${ }^{10}$ For the sake of brevity we abstain from describing in detail the statistics of the independent and control variables included in the analyses. However, the presence of local media in the municipality deserves some consideration. The average value is 2.58 . Still, there are municipalities without a single radio station or newspapers and one with a maximum of 77. Lisbon is the outlier. This variable was tested with and without the Lisbon observation and the results do not differ markedly, so it is included in the final estimations.
} 
maximum likelihood (REML). REML compensates for the loss of degrees of freedom when estimating the fixed effects, producing less biased estimates of the variancecovariance parameters.

The first model - Variance Components Model - does not include any predictor, so that the fixed effects are simply the intercept at the origin and the random effects are the variances/covariances associated with the units of higher hierarchical levels. This base model assumes that voter turnout is estimated by an average constant that varies by municipality and a random error for each parish in each municipality. This model assumes that voter turnout is not influenced by any predictor and the residual varies by municipality. The interest in estimating this model lies in the study of the fraction of the variance between groups (municipalities) relative to the total variance. If this fraction is sufficiently large, the multilevel analysis strategy is justified. The portion of the total variance attributable to the municipal level can be estimated by the Intraclass Correlation Coefficient (ICC). This is a test often used to check for nested data (Shrout and Fleiss 1979; Singer 1998; Raudenbush and Bryk 2002). The ICC is given by the following mathematical expression:

$$
I C C=\frac{\sigma_{\hat{\delta}_{\mathrm{e} j}}^{2}}{\sigma_{\hat{\delta}_{\mathrm{e} j}}^{2}+\sigma_{s_{i j}}^{2}}
$$

where ${ }^{\sigma_{\delta}^{2}}$ is is the variance associated with the random term (variance between

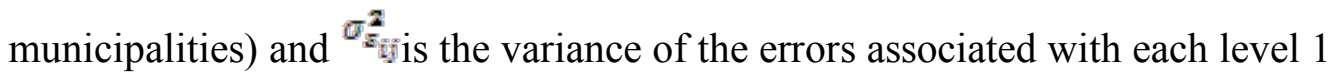
observation at the higher hierarchical level (municipality). The ICC is the proportion of the variance in the SMU council turnout rate explained at the municipal level. For 
example, an ICC of 0 indicates no group effect. Our estimated ICC is $6.77 /(6.98+6.77)$ $=0.49$. This means that $49 \%$ of the total variance in electoral participation is explained by differences between municipalities, a typical value for social sciences phenomena. A high ICC indicates that the hierarchical linear model is the suitable method for analyzing our data. Failing to consider the municipal level would result in type I errors, i.e., levels of statistical significance higher than their true value.

\section{[Insert Table 7 here]}

Column (1) in Table 7 shows the estimate for the intercept indicating that average turnout in SMU elections in all municipalities is $65.41 \%$. This is the value that the dependent variable assumes in the absence of any explanatory variables. Column (2) displays the results for HLM including voter turnout at the municipal level as the only predictor. The result confirms that electoral participation at the municipal level is an important driver of turnout at the SMU level. Despite the relevance of this predictor, its effect does not seem to crowd out the effect of other variables. First, the coefficient remains stable throughout all the different specifications included in Table 7. Second, and most importantly, the inclusion of additional variables in specifications 3-6 improves the quality of adjustment, indicating their relevance as predictors of SMU turnout levels.

The next steps in the incremental approach is the inclusion of the socio-economic variables, first at the SMU level (column 3) and then at both levels of analysis (column 4). The fifth column presents the estimates for a random intercepts model including only predictors at level 1 . The overall significance of the model exceeds $99 \%$ (Wald chi $2=$ 2519.66) and has a log of REML of -13407.3, both indicating a significant increase in the 
quality of fit of the model. Since the results are similar to the ones obtained for the full model (6), we limit the detailed discussion to the full model. The final column in Table 7 displays the results of the random intercepts model including both level 1 and level 2 predictors. The overall significance of this model exceeds 99\% (Wald chi ${ }^{2}=3072.39$ ) and the value of the Log REML is -13352.76, indicating an increase in the quality of adjustment due to the inclusion of predictors at level 2 .

\section{Theoretical Variables}

Our theoretical variables of interest present somewhat conflicting findings. SMU population size is negatively related with electoral participation, validating the first hypothesis $\left(\mathrm{H}_{1}\right)$ of this investigation. An increase of one log in our population variable generates, on average, a decrease in turnout of about 4 percentage points. This also corroborates prior findings that community size has a negative effect on political participation and voter mobilization (e.g., Cancela and Geys 2006; Carr and Tavares 2014; Geys 2006; Frandsen 2002; Oliver 2001; Oliver and Ha 2007; Tavares and Carr 2013; Trounstine 2013; Verba et al. 1978).

The SMU density variable has a negative coefficient. An increase of one log in the density variable originates, on average, a decrease in turnout of 0.57 percentage points. The result of this variable is consistent with the theoretical expectation that in areas with higher population density, elections are likely to be less personal and there is lower social pressure to vote (Blank 1974; Geys 2006; Oliver 2012; Overbye 1995). 
Hypothesis $\mathrm{H}_{4}$ argues that increased territorial fragmentation within the municipality decreases turnout due to the voice-substitution effect associated with excessive fragmentation. The result is inconclusive. The coefficient is negative but misses statistical significance at conventional levels. The level of population concentration is positively associated with turnout, suggesting that in municipalities where population is more heavily concentrated in one or a few SMUs, these tend to display higher turnout levels, therefore confirming $\mathrm{H}_{5}$.

\section{Control Variables}

The socio-demographic variables conform to the expectations. SMUs with a larger proportions of population over 65 years-old tend to display lower rates of electoral participation as evidenced by prior research (Blais et al. 2004; Powell 1986). A SMU unit with a proportion of elderly population ten percentage points above the average (mean $=$ 25.74) experiences, on average, a drop in turnout by 2.3 percentage points. There is a positive relationship between the level of schooling and electoral participation, which is also largely supported by the literature (Blais and Dobrzynska 1998; Timpone 1998; Trounstine 2013; Verba et al. 1995). Substantively, SMU units with a proportion of population with complete higher education of about $27 \%$ (i.e., 10 percentage points above the mean) display, on average, a higher level of electoral participation by 0.8 percentage points.

Two of three political variables have the expected effect on voter turnout. The margin of victory has a negative coefficient, indicating that the greater the difference between the winner and runner-up in elections to the SMU council, the lower the turnout. 
This is consistent with the literature showing that higher levels of interparty competition induce higher rates of electoral participation (Blais and Dobrzynska 1998; Blais 2006; Caren 2007; Tavares and Carr 2013). Substantively, a margin of victory 10 percentage points above the average value (27.36) leads to a decrease of 0.8 percentage points in turnout. SMUs with a greater number of nonpartisan candidates also tend to have higher turnout rates, corroborating the findings of previous studies (Freire et al. 2012). The empirical evidence collected shows that each additional list of candidates without party affiliation produces an increase in turnout of 0.8 percentage points. The political fragmentation variable is not statistically significant. This is partly consistent with other studies showing inconclusive results for this variable, but it is also possible that part of the explanatory power of this variable is undermined by the margin of victory variable, as suggested by Geys (2006).

The control variables included at level 2 behave according to expectations. The most interesting result concerns the local media setting. Municipalities with a larger number of newspapers and radio stations display lower turnout rates, indicating that media competitiveness is ineffective at reducing information asymmetry between candidates and voters and fails to contribute to an increase in mobilization in local elections. Income and the level of religiousness are positively associated with turnout, as predicted by prior empirical works. More surprisingly, perhaps, age is also positively associated with turnout, showing the opposite sign of the same variable at the SMU level. Given the methodological problems associated with the measurement of the Age variable at an aggregate level (i.e. ecological fallacy), this result should be interpreted with significant reservations. 
Interaction Effects

The empirical analysis also tests for possible interaction effects between our theoretical variables: population size and density at the SMU level and fragmentation and concentration at the municipal level. The specifications of the hierarchical linear models in Table 8 include three interaction terms, two of which are cross-level interactions. Without the estimation of these models combined with the graphical representation on Figures 1 to 3 , it would not be possible to make a proper assessment of the conditional relationship of density, fragmentation and population concentration on the effect of size and electoral participation (Brambor et al. 2006). ${ }^{11}$

Figures 1 to 3 show how the marginal effects from changes in the relationship between SMU population and electoral participation vary depending on the levels of population density of the SMU, territorial fragmentation of the municipality, and population concentration in the municipality. The plots were produced using Grinter, a software written for Stata by Frederick Boehmke and illustrate how the marginal effect on $\mathrm{Y}$ (SMU turnout) of a unit increase in $\mathrm{X}_{1}$ (SMU population) changes when $\mathrm{Z}_{1}$ (population density of the parish), $Z_{2}$ (territorial fragmentation of the municipality), and $Z_{3}$ (population concentration across parishes) are increased from the minimum to the maximum value. All other continuous variables in the models are held constant at their

\footnotetext{
${ }^{11}$ These models assume that the effect of the independent variable $(\mathrm{X})$ on the dependent variable $(\mathrm{Y})$, depends on the value of a third variable $(Z)$, such that: $Y=\beta_{0}+\beta_{1} X_{1}+\beta_{2} Z_{1}+\beta_{3} X_{1} Z_{1}+\ldots+\varepsilon$. Brambor, Golder and Clark (2006: 73) state: "As a consequence, the coefficient on the constitutive term X must not be interpreted as the average effect of a change in $\mathrm{X}$ on $\mathrm{Y}$ as it can be in a linear-additive regression model. (...) The coefficient on $X$ only captures the effect on $Y$ when $Z$ is zero. Similarly, it should be obvious that the coefficient on $\mathrm{Z}$ captures the effect of $\mathrm{Z}$ on $\mathrm{Y}$ when $\mathrm{X}$ is zero."
} 
means and dichotomous variables are set to one. The dashed lines in the graphs indicate a $95 \%$ confidence interval.

[Insert Table 8 here]

Column 1 in Table 8 displays the results of an HLM estimation including an interaction term between SMU population size and population density. The coefficient is negative and statistically significant. Figure 1 graphs the relationship between SMU size and voter turnout for the whole range of values of population density. This relationship is negative throughout and becomes increasingly negative as density increases. Larger SMUs are associated with lower turnout rates and this effect becomes more negative as density increases, thus supporting prior arguments and empirical research attesting the detrimental effects of population density to civic and political participation (HoffmanMartinot 1994). The plot allows us to confirm $\mathrm{H}_{3}$ in which it was assumed that population density impacted the relationship between population size and the level of electoral participation in the SMU.

[Insert Figures 1-3 here]

Column 2 in Table 8 shows the findings for the estimation including a multiplicative term between SMU population size and the degree of territorial fragmentation of the municipality. Both the coefficient for this interaction and the second plot fail to validate $\mathrm{H}_{6}$. The results do not support the idea that SMUs in more fragmented cities display lower rates of electoral participation or that the negative effect of SMU size on turnout is deepened when a municipality is divided into more SMUs. In the Portuguese setting the possibility of citizens "voting with their feet" by moving to 
another SMU within the same municipality does not receive empirical support, thus failing to confirm the argument that fragmentation reduces the role of voice and increases the exit threat (Kelleher and Lowery 2004, 2008).

Finally, the last column (3) in Table 8 displays the estimates for the HLM including an interaction term between SMU size and the degree of population concentration across SMUs within the municipality. The coefficient is negative and statistically significant. Figure 3 suggests that municipalities with lower concentration levels are associated with a negative relationship between SMU size and voter turnout. In other words, turnout decreases with SMU size and this effect becomes more intense as the concentration of population in just a few SMUs also increases. This result conflicts with $\mathrm{H}_{7}$ and the expectation that population concentration would mitigate the negative relationship between size and turnout.

The combination of results provided by the three plots allows us to draw some conclusions about how population density, fragmentation and population concentration mediate the negative relationship between the size of the parish and voter turnout. Two mediating variables - density and concentration - compound the negative effect of SMU size on electoral participation. In practice, this suggests that larger SMUs in territorially dense or heavily concentrated municipalities constitute the most adverse setting for electoral participation. It is worth contrasting this result with the findings by Tavares and Carr (2013) for Portuguese municipalities. The authors find that highly fragmented municipalities also display higher turnout rates in municipal elections. The complete picture now indicates that turnout at the municipal level is positively affected by sub- 
municipal fragmentation into SMUs as suggested in Tavares and Carr (2013), but fragmentation itself does not affect voter turnout at the SMU level.

\section{Conclusions and Policy Implications}

This work contributes to the literature on political participation and electoral turnout in several ways. First, to our knowledge, it is the first time that the complex relationship between population size, density, territorial fragmentation, and population concentration in a two-tiered local government system - and their impact on voter turnout in SMUs - is addressed in the literature. The findings for SMUs support prior research conducted at the municipal level suggesting that both size and density decrease voter turnout rates. Second, given the pervasiveness of SMUs across many European countries and the fact that this second-tier of local government is often elected (Hlepas et al. 2018; Klausen, 2018; Lysek, 2018; Swianiewicz, 2018), the results of this empirical study are likely to provide some guidance to government officials regarding the structure of their local government systems. In particular, the level of fragmentation of Portuguese municipalities does not seem to influence voter turnout at the SMU level, suggesting that territorial reforms entailing the creation of elected sub-city districts or SMUs are not hostage to this fragmentation problem. In contrast, population concentration is found to have a positive effect on turnout, thus supporting the argument that concentration in one SMU is likely to generate positive spillovers for other SMUs inside the same municipality. More importantly, it suggests that turnout can be increased by design, i.e., by creating SMUs in areas where population is more heavily concentrated. 
Prior empirical work conducted in the Portuguese setting showed that highly fragmented municipalities are associated with both higher expenditures and larger grants to sub-municipal governments (Tavares and Rodrigues 2015). In contrast, the analysis presented here suggests that excessive sub-municipal fragmentation does not seem to have negative consequences for electoral participation. This finding is consistent with the argument that the combination of high rates of homeownership, low residential mobility and reduced attributions for SMU governments are unlikely to lead Portuguese citizens to 'vote with their feet'. Instead, given this scenario, voting as a 'voice' mechanism is likely to be preferred over 'exit'.

The recent territorial reform of Portuguese SMUs instigated by the Memorandum of Understanding signed by the IMF/EU/ECB and the Portuguese government during the sovereign debt crisis of 2011 introduced amalgamations that reduced the number of SMU units from the 4,259 analyzed here to 3,091. After the institutionalization of this reform, empirical work comparing before-and-after turnout rates in Portuguese SMUs will be of value to determine whether the reform had a positive or a negative impact on political participation.

The findings included in this research suggest that nonpartisan candidates in SMU elections are associated with higher turnout. Future research will explore this link at the both the municipal and sub-municipal levels of analysis by investigating the effects on turnout of the simultaneous presence of partisan and nonpartisan lists in local elections in Portugal. This avenue of research advances our exploration of the role of local government institutions and electoral rules on multiple political and economic outcomes. 


\section{References}

Aars, Jakob and Hans-Erik Ringkjøb. 2005. "Party Politicisation Reversed? Non-Partisan Alternatives in Norwegian Local Politics." Scandinavian Political Studies 28(2): 161181.

Blais, André. 2006. "What Affects Voter Turnout?” Annual Review of Political Science 9: 111-25.

Blais, André and Agnieszka Dobrzynska. 1998. "Turnout in Electoral Democracies." European Journal of Political Research 33(2): 239-262.

Blais, André, Elisabeth Gidengil, Neil Nevitte and Richard Nadeau. 2004. "Where Does Turnout Decline Come From?” European Journal of Political Research 43: 221-236.

Blank, Robert H. 1974. "Socio-Economic Determinism of Voting Turnout: A Challenge." Journal of Politics 36: 731-752.

Brambor, Thomas, W. R. Clark and Matt Golder. 2006. "Understanding Interaction Models: Improving Empirical Analyses.” Political Analysis 14(1): 63-82.

Brennan, Geoffrey and Loren Lomasky. 1997. Democracy and Decision. Cambridge University Press.

Cancela, Joao and Benny Geys. 2016. "Explaining Voter Turnout: A Meta-Analysis of National and Subnational Elections.” Electoral Studies 42: 264-275.

Caren, Neal. 2007. "Big City, Big Turnout? Electoral Participation in American Cities." Journal of Urban Affairs 29(1): 31-46.

Carr, Jered B. and Antonio F. Tavares. 2014. "City Size and Political Participation in Local Government: Reassessing the Contingent Effects of Residential Location Decisions Within Urban Regions." Urban Affairs Review 50(2): 269-302.

Cho, Wendy, James G. Gimpel and Joshua J. Dyck. 2006. "Residential Concentration, Political Socialization, and Voter Turnout." Journal of Politics 68(1): 156-67.

Dahl, Robert A. and Edward R. Tuffe. 1973. Size and Democracy. Stanford, CA: Stanford University Press.

Downs, Anthony. 1957. An Economic Theory of Democracy. New York: Harper \& Row.

Filla, Jackie and Martin Johnson. 2010. "Local News Outlets and Political Participation." Urban Affairs Review 45(5): 679-92.

Fiorina, Morris P. 1976. "The Voting Decision: Instrumental and Expressive Aspects." The Journal of Politics 38(2): 390-413. 
Frandsen, Annie Gaardsted. 2002. "Size and Electoral Participation in Local Elections." Environment and Planning C: Government and Policy 20: 853-69.

Franklin, Mark. N. 2003. “Os Enigmas da Participação Eleitoral.” Análise Social 38 (167): 321-38.

Freire, Andre, Rodrigo Martins and Manuel Meirinho. 2012. "Electoral Rules, Political Competition and Citizens' Participation in the Portuguese Local Elections, 1979-2009." Portuguese Journal of Social Science 11(2): 189-208.

Freire, André and Pedro Magalhães. 2002. A Abstenção Eleitoral em Portugal. Lisboa: ICS.

Geys, Benny. 2006. "Explaining Voter Turnout: A Review of Aggregate-Level Research." Electoral Studies 25: 637-63.

Hlepas, Nikolaos-Komninos, Norbert Kersting, Sabine Kuhlmann, Pawel Swianiewicz, Filipe Teles (editors). 2018. Sub-Municipal Governance in Europe: Decentralization Beyond the Municipal Tier. Palgrave Macmillan.

Hoffman-Martinot, Vincent. 1994. "Voter Turnout in French Municipal Elections.” In L. Lopez-Nieto (ed.). Local Elections in Europe. Barcelona: Institut de Ciènces Politiques I Socials. pp. 13-42.

Jackman, Robert W. 1987. "Political Institutions and Voter Turnout in Industrial Democracies." American Political Science Review 81: 405-24.

Jackman, Robert W., and Ross A. Miller. 1995. "Voter Turnout in the Industrial Democracies During the 1980s." Comparative Political Studies 27 (4): 467-92.

Kaniovski, Serguei and Dennis C. Mueller. 2006. "Community Size, Heterogeneity and Voter Turnouts." Public Choice 129: 399-415.

Kelleher, Christine and David Lowery. 2004. "Political Participation and Metropolitan Institutional Contexts." Urban Affairs Review 39(6): 720-57.

Kelleher, Christine and David Lowery. 2008. "Central City Size, Metropolitan Institutions and Political Participation." British Journal of Political Science 39: 59-92.

Klausen, Jan Erling. 2018. "Sub-municipal Arrangements in Norway: District System in Oslo.” In Hlepas, Nikolaos-Komninos, Norbert Kersting, Sabine Kuhlmann, Pawel Swianiewicz, Filipe Teles (editors). Sub-Municipal Governance in Europe:

Decentralization Beyond the Municipal Tier. Palgrave Macmillan. Pp.145-165.

Kostadinova, Tatiana. 2003. "Voter Turnout Dynamics in Post-Communist Europe." European Journal of Political Research 42: 741-59.

Ladner, Andreas. 2002. "Size and Direct Democracy at the Local Level: The Case of Switzerland." Environment and Planning C: Government and Policy 20: 813-28. 
Lassen, David Dreyer and Søren Serritzlew. 2011. "Jurisdiction Size and Local Democracy: Evidence on Internal Political Efficacy from Large-scale Municipal Reform." American Political Science Review 105(2): 238-258.

Lee, Valerie and Anthony S. Bryk. 1989. "A Multilevel Model of the Social Distribution of High School Achievement.” Sociology of Education 62 (3): 172-192.

Lowery, David and William E. Lyons. 1989. "The Impact of Jurisdictional Boundaries: An Individual Level Test of the Tiebout Model." Journal of Politics 51: 73-97.

Lysek, Jakub. 2018. "The "Little Town-Halls" in the Czech Republic: An Unexploited Potential of Functional Decentralization.” In Hlepas, Nikolaos-Komninos, Norbert Kersting, Sabine Kuhlmann, Pawel Swianiewicz, Filipe Teles (editors). Sub-Municipal Governance in Europe: Decentralization Beyond the Municipal Tier. Palgrave Macmillan. Pp.41-68.

Magalhães, Pedro. 2001. "Desigualdade, Desinteresse e Desconfiança: A Abstenção nas Eleições Legislativas de 1999.” Análise Social 35: 1079-98.

Matsusaka, John G. 1995. "Explaining Voter Turnout Patterns: An Information Theory." Public Choice 84(1-2): 91-117.

Oakerson, Ronald J. 1999. Governing Local Public Economies: Creating the Civic Metropolis. Oakland, CA: ICS Press.

Oakerson, Ronald J. and Roger B. Parks. 2011. "The Study of Local Public Economies: Multi-Organizational, Multi-Level Institutional Analysis and Development." Policy Studies Journal 39 (1): 147-67.

Oliver, J. Eric. 1999. "The Effects of Metropolitan Economic Segregation on Local Civic Participation.” American Journal of Political Science 43 (1): 186-212.

Oliver, J. Eric. 2000. "City Size and Civic Involvement in Metropolitan America." American Political Science Review 94 (2): 361-73.

Oliver, J. Eric. 2001. Democracy in Suburbia. Princeton, NJ: Princeton University Press.

Oliver, J. Eric. 2012. Local Elections and the Politics of Small-Scale Democracy. Princeton, New Jersey: Princeton University Press.

Oliver, J. Eric and Shang E. Ha. 2007. "Vote Choice in Suburban Elections." American Political Science Review 101 (3): 393-407.

Overbye, E. 1995. "Making a Case for the Rational Self-Regarding «Ethical» Voter... And Solving the «Paradox of Not Voting» in the Process." European Journal of Political Research 27: 369-96.

Pereira, A. and Almeida C. D. 1985. Conhecer as Autarquias Locais. Porto: Porto Editora. 
Powell, G. Bingham. 1986. "American Voter Turnout in Comparative Perspectives." American Political Science Review 80: 17-43.

Raudenbush, Stephen W. and Anthony S. Bryk. 1986. "A Hierarchical Models for Studying School Effects.” Sociology of Education 59 (1): 1-17.

Raudenbush, Stephen W. and Anthony S. Bryk. 2002. Hierarchical Linear Models: Applications and Data Analysis Methods, $2^{\text {nd }}$ ed. Thousand Oaks, CA: Sage.

Riker, William H. and Peter C. Ordeshook. 1968. "A Theory of the Calculus of Voting." American Political Science Review 62(1): 25-42.

Ross, Bernard H. and Myron A. Levine. 2001. Urban Politics: Power in Metropolitan America, 6th Ed. Itasca, IL: F.E. Peacock.

Schneider, Mark. 1989. The Competitive City. Pittsburgh, PA: University of Pittsburgh Press.

Shrout, Patrick E. and Joseph L. Fleiss. 1979. "Intraclass Correlations: Uses in Assessing Rater Reliability." Psychological Bulletin 2: 420-28.

Schuessler, Alexander A. 2000. A Logic of Expressive Choice. Princeton University Press.

Singer, Judith D. 1998. "Using SAS PROC Mixed to Fit Multilevel Models, Hierarchical Models, and Individual Growth Models." Journal of Educational and Behavioral Statistics 23(4): 323-55.

Squire, Peverill and Eric R. A. N. Smith. 1988. "The Effects of Partisan Information on Voters in Nonpartisan Elections.” Journal of Politics 50: 169-79.

Squire, Peverill, Raymond. E. Wolfinger and David P. Glass. 1987. "Residential Mobility and Voter Turnout." American Political Science Review 81(1): 45-66.

Steenbergen, Marco R. and Bradford S. Jones. 2002. "Modeling Multilevel Data Structures." American Journal of Political Science 46(1): 218-237.

Stein, Robert M. and Gavin Dillingham. 2004. "Political Participation in an Urbanized Society." Paper presented at the Annual Meeting of the American Political Science Association, Chicago, IL, September 2-6.

Struthers, John and Alistair Young. 1989. "Economics of Voting: Theories and Evidence." Journal of Economic Studies 16(5): 3-42.

Swianiewicz. Paweł. 2014. "Intra-Municipal Units in Urban Political Systems in Poland: Vicious Roundabout of Marginalization or Dead-End Street?" The NISPAcee Journal of Public Administration and Policy 7(2): 173-198.

Swianiewicz. Paweł. 2018. "New Experiments of Maintenance of Old Traditions? Dual System of Sub-municipal Units in Poland.” In Hlepas, Nikolaos-Komninos, Norbert 
Kersting, Sabine Kuhlmann, Pawel Swianiewicz, Filipe Teles (editors). Sub-Municipal Governance in Europe: Decentralization Beyond the Municipal Tier. Palgrave Macmillan. Pp.167-192.

Tavares, António F. and Jered B. Carr. 2013. "So Close, Yet So Far Away? The Effects of City Size, Density, and Growth on Local Civic Participation." Journal of Urban Affairs 35(3): 283-302.

Tavares, António F. and Miguel Rodrigues. 2015. "The Economic and Political Impacts of Top-Down Territorial Reforms: The Case of Portuguese Parishes." Local Government Studies 41(6): 956-976.

Timpone, Richard J. 1998. "Ties That Bind: Measurement, Demographics, and Social Connectedness." Political Behavior 20(1):53-77.

Trounstine, Jessica. 2013. "Turnout and Incumbency in Local Elections.” Urban Affairs Review 49(2): 167-189.

Verba, Sidney, Kay Schlozman and Henry Brady. 1995. Voice and Equality. Cambridge, MA: Harvard University Press.

Verba, Sidney and Norman Nie. 1972. Participation in America: Political Democracy and Social Equality. New York, NY: Harper and Row.

Verba, Sidney, Norman H. Nie, and Jae-on Kim. 1978. Participation and Political Equality: A Cross-National Comparison. Cambridge: Cambridge University Press.

Western, Bruce. 1998. "Causal Heterogeneity in comparative Research: A Bayesian Hierarchical Modelling Approach.” American Journal of Political Science 42 (4): 1233-59.

Wood, Curtis. 2002. "Voter Turnout in City Elections." Urban Affairs Review 38(2): 209231.

Zhu, Weimo. 1997. "A Multilevel Analysis of School Factors Associated With Health-Related Fitness." Research Quarterly for Exercise and Sport 68(2): 125-135. 
Table 1: SMUs per number of registered voters

\begin{tabular}{|c|c|c|}
\hline Number of Registered Voters & SMUs & \% \\
\hline Less than 150 & 177 & 4.16 \\
\hline Between 150 and 1,000 & 1,989 & 46.79 \\
\hline Between 1,000 and 5,000 & 1,637 & 38.51 \\
\hline Between 5,000 and 20,000 & 375 & 8.82 \\
\hline More than 20,000 & 73 & 1.72 \\
\hline Total SMUs & $\mathbf{4 , 2 5 1}$ & $\mathbf{1 0 0}$ \\
\hline
\end{tabular}

Source: DGAL - Direcção Geral das Autarquias Locais (2003).

Table 2: SMUs per area in square kilometers

\begin{tabular}{|c|c|c|}
\hline SMUs & SMUs & \% \\
\hline Less than 1 sq. km & 70 & 1.65 \\
\hline Between 1 and 5 sq. kms & 943 & 22.18 \\
\hline Between 5 and 10 sq. kms & 931 & 21.90 \\
\hline Between 10 and 50 sq. kms & 1928 & 45.35 \\
\hline Between 50 and 100 sq. kms & 226 & 5.32 \\
\hline Between 100 and 200 sq. kms & 123 & 2.89 \\
\hline Between 200 and 400 sq. kms & 29 & 0.68 \\
\hline More than 400 sq. kms & 1 & 0.02 \\
\hline Total SMUs & $\mathbf{4 , 2 5 1}$ & $\mathbf{1 0 0}$ \\
\hline
\end{tabular}

Source: DGAL - Direç̧ão Geral das Autarquias Locais (2003). 
Table 3: SMU Council and SMU Executive Size

\begin{tabular}{|c|c|c|c|}
\hline Registered Voters & $\begin{array}{c}\text { SMU } \\
\text { Council }\end{array}$ & Registered Voters & $\begin{array}{c}\text { SMU } \\
\text { Executive }\end{array}$ \\
\hline Less than 1,000 & 7 & & 2 \\
\hline Between 1,000 and 5,000 & 9 & Less than 5,000 & 4 \\
\hline Between 5,000 and 20,000 & 13 & Between 5,000 and 20,000 & 6 \\
\hline Between 20,000 and 30,000 & 19 & More than 20,000 & \\
\hline For each additional 10,000 & +1 & & \\
\hline
\end{tabular}

Table 4: Number of SMUs per Municipality

\begin{tabular}{|c|c|c|}
\hline SMUs & Number of Municipalities & Percentage \\
\hline Less than 10 SMUs & 164 & 53.25 \\
\hline Between 10 and 20 & 88 & 28.57 \\
\hline Between 20 and 30 & 27 & 8.77 \\
\hline Between 30 and 40 & 18 & 5.84 \\
\hline Between 40 and 50 & 2 & 0.65 \\
\hline More than 50 & 9 & 2.92 \\
\hline Total number of municipalities & $\mathbf{3 0 8}$ & $\mathbf{1 0 0 . 0 0}$ \\
\hline
\end{tabular}

Source: DGAL - Direcção Geral das Autarquias Locais, 2003. 
Table 5: Variables, Sources and Expected Signs

\begin{tabular}{|c|c|c|c|}
\hline Dependent Variable & Indicator & \multicolumn{2}{|c|}{ Source } \\
\hline Electoral Participation & $\begin{array}{l}\text { Voter turnout in the } 2009 \text { parish council } \\
\text { election }\end{array}$ & \multicolumn{2}{|r|}{ DGAI } \\
\hline Level 1 Variables (Parishes) & Indicator & Source & Expected Sign \\
\hline Population Size (X1j) & Parish population (log) & INE & $+/-$ \\
\hline Population Density (X2j) & $\begin{array}{l}\text { Population divided by area in square kms } \\
\qquad(\log )\end{array}$ & INE & $+/-$ \\
\hline Age $(X 3 j)$ & Proportion of population over 65 years-old & INE & - \\
\hline Education (X4j) & $\begin{array}{c}\text { Proportion of population with high school } \\
\text { education }\end{array}$ & INE & + \\
\hline Margin of Victory (X5j) & $\begin{array}{l}\text { Difference in percentage points between the } \\
\text { first two lists in parish council elections }\end{array}$ & DGAI & - \\
\hline Political Fragmentation (X6j) & Number of candidates & DGAI & - \\
\hline Nonpartisan Candidates (X7j) & $\begin{array}{l}\text { Number of candidates without national } \\
\text { party affiliation }\end{array}$ & DGAI & + \\
\hline Island SMUs (X8j) & Dummy variable (1=Island SMU) & INE & - \\
\hline $\begin{array}{l}\text { Level } 2 \text { Variables } \\
\text { (Municipalities) }\end{array}$ & Indicator & Source & Expected Sign \\
\hline Population Size (Xi1) & Municipal population (log) & INE & $+/-$ \\
\hline Population Density (Xi2) & $\begin{array}{l}\text { Municipal population divided by the area of } \\
\text { the municipality in square } \mathrm{kms}(\log )\end{array}$ & INE & $+/-$ \\
\hline $\begin{array}{l}\text { Territorial Fragmentation } \\
\qquad(\mathrm{Xi3})\end{array}$ & $\begin{array}{l}\text { Number of parishes in the municipality } \\
\qquad(\log )\end{array}$ & ANMP & - \\
\hline $\begin{array}{l}\text { Population Concentration } \\
\qquad(\mathrm{Xi} 4)\end{array}$ & $\begin{array}{l}\text { Herfindahl Index showing concentration of } \\
\text { municipal population within its parishes }\end{array}$ & INE & + \\
\hline Age $(\mathrm{Xi5})$ & Population over 65 years-old & INE & - \\
\hline Education (Xi6) & $\begin{array}{c}\text { Proportion of population with high school } \\
\text { education }\end{array}$ & INE & + \\
\hline Income $(\mathrm{Xi7})$ & Average monthly earnings & INE & + \\
\hline $\begin{array}{l}\text { Local Media Competition } \\
\qquad \text { (Xi8) }\end{array}$ & Number of newspapers and radio stations & NEAPP & + \\
\hline Margin of Victory (Xi9) & $\begin{array}{l}\text { Difference in percentage points between the } \\
\text { first two lists in mayoral elections }\end{array}$ & INE & - \\
\hline Religiousness (Xi10) & $\begin{array}{c}\text { Proportion of Catholic weddings in the } \\
\text { municipality }\end{array}$ & INE & + \\
\hline
\end{tabular}




\begin{tabular}{|l|l|l|l|}
\hline Electoral Participation (Xi11) & Voter turnout in the 2009 mayoral elections & DGAI & + \\
\hline
\end{tabular}

Table 6: Summary Statistics

\begin{tabular}{lccccc}
\hline VARIABLES & Obs. & Mean & $\begin{array}{c}\text { Standard } \\
\text { Deviation }\end{array}$ & Min. & Max. \\
\hline Level 1 (SMUs) & & & & & \\
& & & & & \\
Electoral participation (SMUs) & 4,117 & 65.54 & 9.495 & 31.36 & 92.11 \\
Population (log) & 4,260 & 6.864 & 1.321 & 3.434 & 11.10 \\
Density (log) & 4,260 & 4.447 & 1.751 & -0.118 & 10.29 \\
Age & 4,260 & 25.74 & 12.71 & 0 & 95 \\
Education & 4,260 & 16.91 & 8.615 & 0 & 78.47 \\
Margin of victory & 4,257 & 27.36 & 22.29 & 0 & 100 \\
Political fragmentation & 4,259 & 2.770 & 1.196 & 0 & 7 \\
Nonpartisan candidates & 4,259 & 0.186 & 0.424 & 0 & 2 \\
Island SMUs & 4,260 & 0.049 & 0.217 & 0 & 1 \\
& & & & & \\
Level 2 (municipalities) & & & & & \\
& & & & & \\
Electoral participation & 4,260 & 63.43 & 6.860 & 44.05 & 81.11 \\
Population size & 4,260 & 9.795 & 1.126 & 6.064 & 13.14 \\
Population density & 4,260 & 4.447 & 1.459 & 1.738 & 8.901 \\
Territorial fragmentation & 4,260 & 2.311 & 0.897 & 0 & 4.489 \\
Population concentration & 4,260 & 0.142 & 0.110 & 0.0196 & 1 \\
Age & 4,260 & 9,333 & 14,558 & 71 & 113,651 \\
Education & 4,143 & 81.76 & 4.981 & 50 & 100 \\
Income & 4,260 & 824.3 & 143.8 & 616.7 & 1,693 \\
Local media & 4,260 & 2.577 & 8.718 & 0 & 77 \\
Religiousness & 4,260 & 49.85 & 15.38 & 0 & 84 \\
Urban land use & 4,045 & 2,618 & 2,233 & 92.30 & 12,668 \\
Margin of victory & 4,260 & 20.62 & 14.14 & 0.0700 & 63.41 \\
Turnout ratio (SMUs/MUN) & 4,117 & 1.036 & 0.116 & 0.546 & 1.662 \\
& & & & & \\
Number of groups & 307 & 307 & 307 & 307 & 307 \\
\hline
\end{tabular}


Table 7: Hierarchical Linear Regression Models

(Dependent variable: SMU council turnout rate)

VARIABLES

\section{Level 1 (SMUs)}

Population $(\log )$

Density $(\log )$

Age

Education

Margin of victory

Political fragmentation

Nonpartisan candidates

Island SMUs

\section{Level 2 (Municipalities)}

Population size

Population density

Territorial fragmentation $(\log )$

Population concentration

Age

Income

Local media

Religiousness

Margin of victory

Electoral participation (MUN)

Constant

Random effects

Residual
(1)

(2)

(3)

(4)

(5)

(6) 


$\begin{array}{ccccccc} & (0.080) & (0.078) & (0.073) & (0.072) & (0.069) & (0.069) \\ \text { Constant } & 6.754 & 1.284 & 2.337 & 1.712 & 2.370 & 1.831 \\ & (0.314) & (0.138) & (0.170) & (0.151) & (0.166) & (0.148)\end{array}$

\begin{tabular}{lcccccc} 
Quality of adjustment & & & & & & \\
Log REML & -14199.281 & -13850.584 & -13579.574 & -13518.17 & -13407.295 & -13352.762 \\
AIC & 28404.56 & 27709.17 & 27177.15 & 27070.34 & 26838.59 & 26747.52 \\
BIC & 28423.53 & 27734.46 & 27234.05 & 27177.83 & 26914.46 & 26880.3 \\
Wald chi2 & --- & 2170.62 & 2058.49 & 2683.26 & 2519.66 & 3072.39 \\
& & & & & & \\
& & & & & & \\
Observations (SMUs) & 4,117 & 4,117 & 4,117 & 4,117 & 4,117 & 4,117 \\
Number of groups (MUN) & 307 & 307 & 307 & 307 & 307 & 307 \\
\hline
\end{tabular}

Note: Robust standard errors in parentheses. ${ }^{* * *} \mathrm{p}<.01 ; * * \mathrm{p}<.05 ; * \mathrm{p}<.10$; for two-tailed tests. 
Table 8: Hierarchical Linear Regression Models with Interaction Effects (Dependent variable: SMU council turnout rate)

\begin{tabular}{|c|c|c|c|}
\hline VARIABLES & $\begin{array}{c}(1) \\
\text { popXdens }\end{array}$ & $\begin{array}{c}\text { (2) } \\
\text { popXfrag }\end{array}$ & $\begin{array}{c}\text { (3) } \\
\text { popXconc }\end{array}$ \\
\hline \multicolumn{4}{|l|}{ Level 1 (SMUs) } \\
\hline Population (log) & $\begin{array}{c}-2.378 * * * \\
(0.298)\end{array}$ & $\begin{array}{c}-3.671 * * * \\
(0.299)\end{array}$ & $\begin{array}{c}-3.793 * * * \\
(0.206)\end{array}$ \\
\hline Density (log) & $\begin{array}{c}1.934 * * * \\
(0.402)\end{array}$ & $\begin{array}{c}-0.570 * * * \\
(0.137)\end{array}$ & $\begin{array}{c}-0.551 * * * \\
(0.137)\end{array}$ \\
\hline Age & $\begin{array}{c}-0.189 * * * \\
(0.0148)\end{array}$ & $\begin{array}{c}-0.226 * * * \\
(0.0138)\end{array}$ & $\begin{array}{c}-0.229 * * * \\
(0.0139)\end{array}$ \\
\hline Education & $\begin{array}{c}0.0851 * * * \\
(0.0177)\end{array}$ & $\begin{array}{c}0.0791 * * * \\
(0.0178)\end{array}$ & $\begin{array}{c}0.0756^{* * * *} \\
(0.0178)\end{array}$ \\
\hline Margin of victory & $\begin{array}{c}-0.0805 * * * \\
(0.00504)\end{array}$ & $\begin{array}{c}-0.0828^{* * * *} \\
(0.00507)\end{array}$ & $\begin{array}{c}-0.0824 * * * \\
(0.00506)\end{array}$ \\
\hline Political fragmentation & $\begin{array}{l}0.281^{*} \\
(0.150)\end{array}$ & $\begin{array}{c}0.220 \\
(0.152)\end{array}$ & $\begin{array}{c}0.200 \\
(0.152)\end{array}$ \\
\hline Nonpartisan candidates & $\begin{array}{c}0.789 * * * \\
(0.253)\end{array}$ & $\begin{array}{c}0.847 * * * \\
(0.256)\end{array}$ & $\begin{array}{c}0.856^{* * *} * \\
(0.256)\end{array}$ \\
\hline Island SMUs & $\begin{array}{l}-0.423 \\
(0.670)\end{array}$ & $\begin{array}{l}-0.663 \\
(0.692)\end{array}$ & $\begin{array}{l}-0.751 \\
(0.688)\end{array}$ \\
\hline Level 2 (Municipalities) & & & \\
\hline Population size & $\begin{array}{c}0.952 * * * \\
(0.302)\end{array}$ & $\begin{array}{c}0.900 * * * \\
(0.315)\end{array}$ & $\begin{array}{c}0.933 * * * \\
(0.312)\end{array}$ \\
\hline Population density & $\begin{array}{c}-0.527 * * * \\
(0.202)\end{array}$ & $\begin{array}{c}-0.509^{* *} \\
(0.210)\end{array}$ & $\begin{array}{c}-0.522^{* *} \\
(0.208)\end{array}$ \\
\hline Territorial fragmentation & $\begin{array}{l}-0.329 \\
(0.226)\end{array}$ & $\begin{array}{c}0.867 \\
(0.798)\end{array}$ & $\begin{array}{l}-0.331 \\
(0.234)\end{array}$ \\
\hline Population concentration & $\begin{array}{c}8.536^{* * * *} \\
(1.393)\end{array}$ & $\begin{array}{c}8.527 * * * \\
(1.431)\end{array}$ & $\begin{array}{c}21.27 * * * \\
(6.187)\end{array}$ \\
\hline Age & $\begin{array}{c}0.000272 * * * \\
(3.02 \mathrm{e}-05)\end{array}$ & $\begin{array}{c}0.000235^{* * *} \\
(3.08 \mathrm{e}-05)\end{array}$ & $\begin{array}{c}0.000225^{* * *} \\
(3.06 \mathrm{e}-05)\end{array}$ \\
\hline Income & $\begin{array}{c}0.00431 * * * \\
(0.00149)\end{array}$ & $\begin{array}{c}0.00432 * * * \\
(0.00154)\end{array}$ & $\begin{array}{c}0.00423 * * * \\
(0.00153)\end{array}$ \\
\hline Local media & $\begin{array}{c}-0.356^{* * * *} \\
(0.0468)\end{array}$ & $\begin{array}{c}-0.316^{* * * *} \\
(0.0489)\end{array}$ & $\begin{array}{c}-0.302 * * * \\
(0.0482)\end{array}$ \\
\hline Religiousness & $\begin{array}{l}0.0197^{*} \\
(0.0111)\end{array}$ & $\begin{array}{c}0.0228^{* *} \\
(0.0115)\end{array}$ & $\begin{array}{c}0.0232 * * \\
(0.0114)\end{array}$ \\
\hline Margin of victory & $\begin{array}{l}-0.00363 \\
(0.0102)\end{array}$ & $\begin{array}{l}-0.00347 \\
(0.0107)\end{array}$ & $\begin{array}{l}-0.00327 \\
(0.0106)\end{array}$ \\
\hline Electoral participation & $\begin{array}{c}0.801 * * * \\
(0.0251)\end{array}$ & $\begin{array}{c}0.794 * * * \\
(0.0260)\end{array}$ & $\begin{array}{c}0.783 * * * \\
(0.0264)\end{array}$ \\
\hline popXdens & $\begin{array}{c}-0.334 * * * \\
(0.0504)\end{array}$ & ---- & --- \\
\hline popXfrag & ---- & $\begin{array}{l}-0.169 \\
(0.109)\end{array}$ & ---- \\
\hline popXconc & ---- & ---- & $\begin{array}{c}-1.659^{* *} \\
(0.789)\end{array}$ \\
\hline Constant & $24.76^{* * *}$ & $36.20 * * *$ & $37.58 * * *$ \\
\hline
\end{tabular}




\section{Random effects}

Residual

$\begin{array}{ccc}6.018 & 6.032 & 6.034 \\ (0.069) & (0.069) & (0.069) \\ 1.709 & 1.849 & 1.818 \\ (0.147) & (0.148) & (0.149)\end{array}$

Constant

$\begin{array}{ccc}-13331.2 & -13351.6 & -13350.6 \\ 26706.41 & 26747.14 & 26745.11 \\ 26845.51 & 26886.25 & 26884.21 \\ 3254.97 & 3059.62 & 3090.84\end{array}$

Quality of adjustment

Log REML

AIC

BIC

Wald chi2

Observations (SMUs)

Number of groups (MUN)
4,117

307
4,117

307
4,117

307

Note: Robust standard errors in parentheses. ${ }^{* * *} \mathrm{p}<.01 ; * * \mathrm{p}<.05 ; * \mathrm{p}<.10$; for two-tailed tests. 
Figure 1: Contingent Effects of Population Density on the Relationship between SMU Size and Electoral Participation

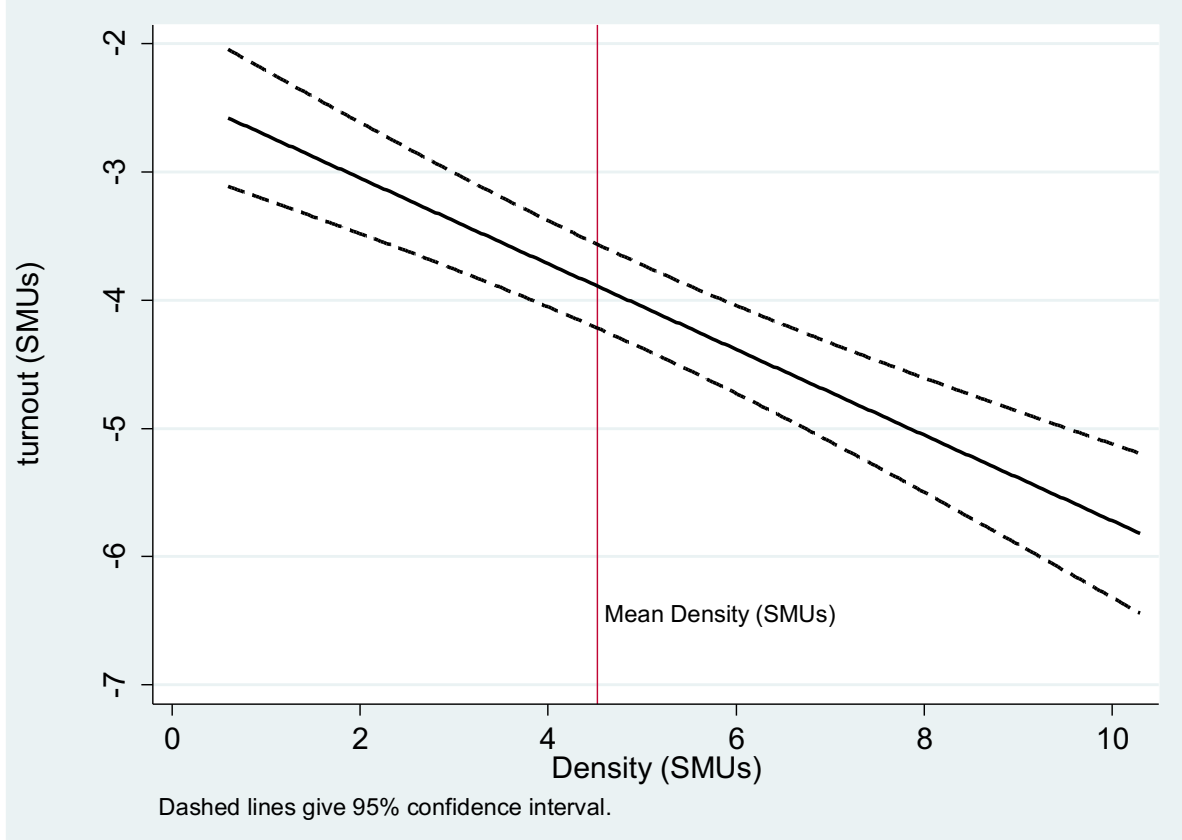

Figure 2: Contingent Effects of Municipal Fragmentation on the Relationship between SMU Size and Electoral Participation

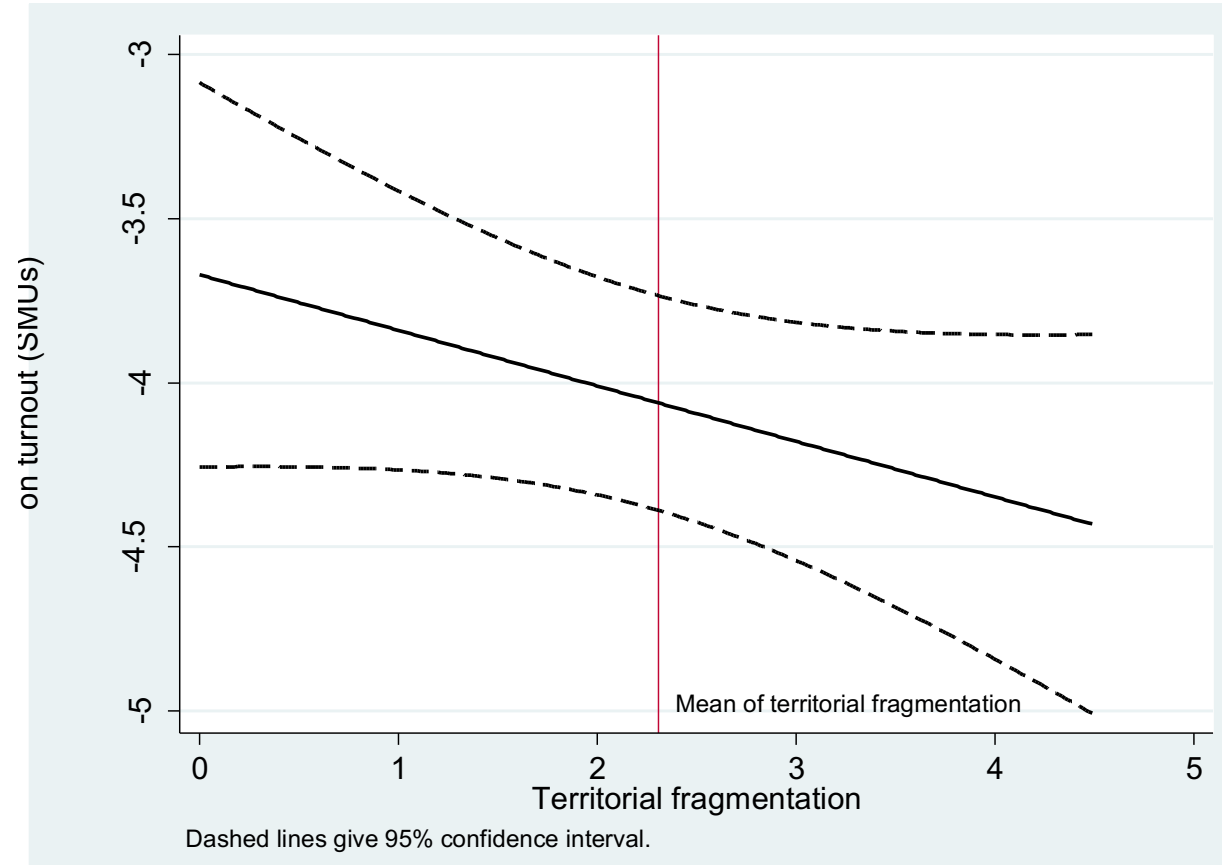


Figure 3: Contingent Effects of Municipal Population Concentration on the Relationship between SMU Size and Electoral Participation

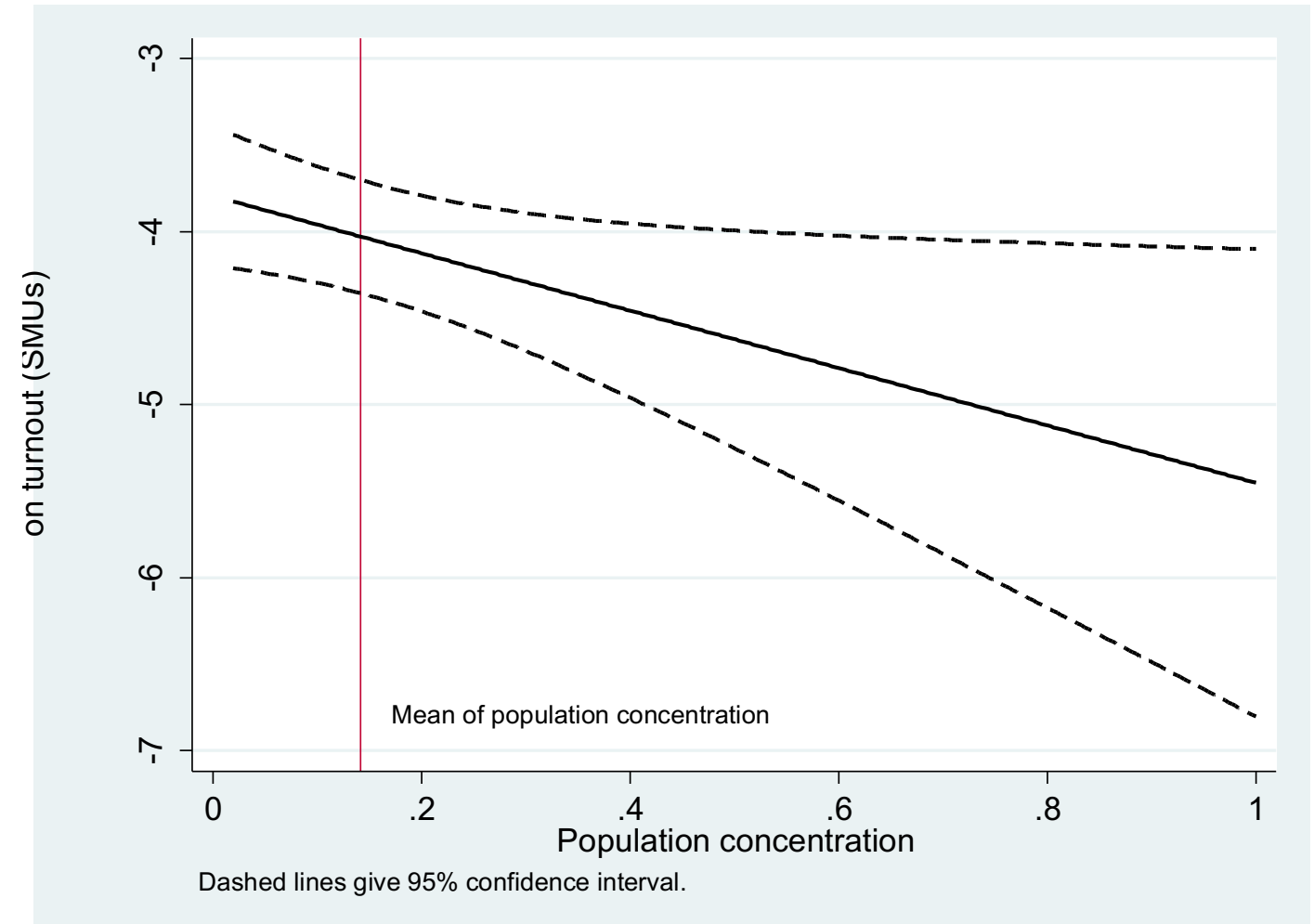




\section{Appendix A - Hierarchical Linear Regression Models}

\begin{tabular}{|c|c|c|c|}
\hline VARIABLES & (A) & (B) & (C) \\
\hline \multicolumn{4}{|l|}{ Fixed effects } \\
\hline \multicolumn{4}{|l|}{ Level 1 (SMUs) } \\
\hline Population (log) & $\begin{array}{c}-4.073 * * * \\
(0.169)\end{array}$ & $\begin{array}{c}-4.209 * * * \\
(0.171)\end{array}$ & $\begin{array}{c}-0.0658 * * * \\
(0.00277)\end{array}$ \\
\hline Density $(\log )$ & $\begin{array}{c}-0.593 * * * \\
(0.140)\end{array}$ & $\begin{array}{c}-0.548^{* * * *} \\
(0.140)\end{array}$ & $\begin{array}{c}-0.0102 * * * \\
(0.00231)\end{array}$ \\
\hline Age & $\begin{array}{c}-0.228 * * * \\
(0.0141)\end{array}$ & $\begin{array}{c}-0.235 * * * \\
(0.0147)\end{array}$ & $\begin{array}{c}-0.00364 * * * \\
(0.000231)\end{array}$ \\
\hline Education & $\begin{array}{c}0.0774 * * * \\
(0.0180)\end{array}$ & $\begin{array}{c}0.0995 * * * \\
(0.0187)\end{array}$ & $\begin{array}{c}0.00137 * * * \\
(0.000297)\end{array}$ \\
\hline Margin of victory & $\begin{array}{c}-0.0831 * * * \\
(0.00515)\end{array}$ & $\begin{array}{c}-0.0810 * * * \\
(0.00513)\end{array}$ & $\begin{array}{c}-0.00125 * * * \\
(8.31 \mathrm{e}-05)\end{array}$ \\
\hline Political fragmentation & $\begin{array}{c}0.209 \\
(0.154)\end{array}$ & $\begin{array}{l}0.331 * * \\
(0.158)\end{array}$ & $\begin{array}{l}0.00459 * \\
(0.00253)\end{array}$ \\
\hline Nonpartisan candidates & $\begin{array}{c}0.867 * * * \\
(0.259)\end{array}$ & $\begin{array}{c}0.840 * * * \\
(0.256)\end{array}$ & $\begin{array}{c}0.0123 * * * \\
(0.00427)\end{array}$ \\
\hline Island SMUs & $\begin{array}{l}-0.589 \\
(0.752)\end{array}$ & ---- & $\begin{array}{l}-0.00941 \\
(0.0123)\end{array}$ \\
\hline \multicolumn{4}{|l|}{ Level 2 (Municipalities) } \\
\hline Population size & $\begin{array}{c}0.952 * * * \\
(0.328)\end{array}$ & $\begin{array}{c}0.661 * * \\
(0.317)\end{array}$ & $\begin{array}{l}0.0203 * * * \\
(0.00569)\end{array}$ \\
\hline Population density & $\begin{array}{c}-0.555^{* *} \\
(0.216)\end{array}$ & $\begin{array}{l}-0.384^{*} \\
(0.210)\end{array}$ & $\begin{array}{c}-0.0107 * * * \\
(0.00382)\end{array}$ \\
\hline Territorial fragmentation (log) & $\begin{array}{l}-0.336 \\
(0.246)\end{array}$ & $\begin{array}{l}-0.317 \\
(0.234)\end{array}$ & $\begin{array}{l}-0.0106 * * \\
(0.00427)\end{array}$ \\
\hline Population concentration & $\begin{array}{c}8.812 * * * \\
(1.521)\end{array}$ & $\begin{array}{c}10.49 * * * \\
(1.519)\end{array}$ & $\begin{array}{l}0.119 * * * \\
(0.0249)\end{array}$ \\
\hline Education & $\begin{array}{l}0.00322 \\
(0.0347)\end{array}$ & ---- & ---- \\
\hline Age & $\begin{array}{c}0.000235^{* * * *} \\
(3.13 \mathrm{e}-05)\end{array}$ & $\begin{array}{c}0.000192 * * * \\
(3.48 \mathrm{e}-05)\end{array}$ & $\begin{array}{c}4.88 \mathrm{e}-06 * * * \\
(5.52 \mathrm{e}-07)\end{array}$ \\
\hline Income & $\begin{array}{l}0.00390^{* *} \\
(0.00161)\end{array}$ & $\begin{array}{c}0.00460 * * * \\
(0.00167)\end{array}$ & $\begin{array}{c}0.000112 * * * \\
(2.68 \mathrm{e}-05)\end{array}$ \\
\hline Local media & $\begin{array}{c}-0.308 * * * \\
(0.0495)\end{array}$ & $\begin{array}{c}-0.277 * * * \\
(0.0510)\end{array}$ & $\begin{array}{c}-0.00645^{* * * *} \\
(0.000895)\end{array}$ \\
\hline Religiousness & $\begin{array}{l}0.0215^{*} \\
(0.0127)\end{array}$ & $\begin{array}{c}0.0120 \\
(0.0126)\end{array}$ & $\begin{array}{l}-0.000131 \\
(0.000199)\end{array}$ \\
\hline Urban land use & ---- & $\begin{array}{c}0.000302 * * * \\
(0.000113)\end{array}$ & ---- \\
\hline Margin of victory & $\begin{array}{l}-0.00234 \\
(0.0109)\end{array}$ & $\begin{array}{l}-0.00332 \\
(0.0110)\end{array}$ & $\begin{array}{l}-3.17 \mathrm{e}-05 \\
(0.000194)\end{array}$ \\
\hline Electoral participation (MUN) & $\begin{array}{c}0.790 * * * \\
(0.0279)\end{array}$ & $\begin{array}{c}0.831 * * * \\
(0.0277)\end{array}$ & ---- \\
\hline Constant & $\begin{array}{c}39.35 * * * \\
(4.380)\end{array}$ & $\begin{array}{c}38.41 * * * \\
(3.348)\end{array}$ & $\begin{array}{c}1.371 * * * \\
(0.0457)\end{array}$ \\
\hline \multicolumn{4}{|l|}{ Random effects } \\
\hline Residual & 6.038 & 5.974 & .099 \\
\hline
\end{tabular}




\begin{tabular}{lccc} 
& $(.070)$ & $(.070)$ & $(.001)$ \\
Constant & 1.878 & 1.812 & .036 \\
& $(.152)$ & $(.153)$ & $(.003)$ \\
Quality of adjustment & & & \\
Log REML & -12993.2 & -12633.5 & 3539.7 \\
AIC & 26030.38 & 25308.93 & -7039.49 \\
BIC & 26168.87 & 25440.61 & -6913.03 \\
Wald chi2 & 2879.70 & 2901.90 & 1120.50 \\
& & & \\
Observations (SMUs) & 4,005 & 3,908 & 4,117 \\
Number of groups (MUN) & 285 & 277 & 307 \\
\hline
\end{tabular}

Note: Robust standard errors in parentheses. ${ }^{* * *} \mathrm{p}<.01 ; * * \mathrm{p}<.05 ; * \mathrm{p}<.10$; for two-tailed tests. 